\title{
Erratum to: Role of family history and tumor location on prognosis of patients with colorectal cancer and synchronous metastases
}

\author{
Giuseppe Colloca $^{1} \cdot$ Antonella Venturino $^{1}$
}

Published online: 2 August 2017

(C) Springer-Verlag GmbH Germany 2017

Erratum to: Int J Colorectal Dis (2017) 32:1069-1072. https://doi.org/10.1007/s00384-017-2831-7

The original version of this article, unfortunately, contained an error.

The first and family names of the authors were interchanged. The correct author names are now correctly presented in this article.

The online version of the original article can be found at http://dx.doi.org/ 10.1007/s00384-017-2831-7

\footnotetext{
Giuseppe Colloca

g.colloca@katamail.com

1 Department of Oncology, G. Borea Hospital, Via G. Borea n. 56, 18038 Sanremo, Imperia, Italy
} 